\title{
DE BASIS.
}

De redactie van „Koers" vraagt mij een bijdrage voor dit nummer, dat zal worden opgedragen aan de Vrije Universiteit.

Gaarne voldoen ik aan dit verzoek. Ook omdat ik daarvoor uitdrukking kan geven aan mijn dankbaarheid voor het feit, dat er onder onze vrienden in Zuid-Afrika zo veel genegenheid leeft voor de Vrije Universiteit.

En daar zij leven uit hetzelfde beginsel als wij, en daar zij tevens leven in een wereld met dezelfde gevaren, ook op wetenschappelijk erf, is het een niet zware opdracht over en weer woorden te spreken, die in Nederland en Zuid-Afrika duidelijke taal zijn.

De gevaren, waardoor wij bedreigd worden, zijn gevaren, die eveneens het Christelijk leven en het Christelijk denken in Zuid-Afrika dreigen te ondergraven.

Natuurlijk zijn deze gevaren van allerlei aard.

Het ééne gevaar dreigt meer hier, het andere daar. Dat ik iets ga zeggen vanuit de gezichtshoek van mijn eigen vakgebied, zal wel niemand verbazen.

De kring van „Koers” en van de Vrije Universiteit willen beiden leven vanuit het Christelijk geloof. Maar nu is het merkwaardig te constateren hoe allerwege in de wereld, waar door Christenen wetenschap beoefend wordt, basisvisie dreigt te vervagen.

Er zijn Christenen, die een wetenschap doen, bijvoorbeeld aan paedagogiek of psychologie, en die toch altijd het gevoel hebben dat de situatie deze is, dat er enerzijds is "de" wetenschap, zoals die in het algemeen beoefend wordt, en anderzijds het Christendom. Nu eens blijft men spreken over het Christelijk geloof, maar ziet dat dan als een correctie óp, of als een addendum bij datgene wat de „wetenschap" ons biedt. Dan weer gaat men een stap verder, en spreekt over de theologie, die een taak heeft naast het eigen vakgebied, en die dan bepaalde kwesties maar moet uitmaken.

Zo zeide eens een hoogleraar, die prijs stelde op de naam Calvinist, sprekend over de ziel van de mens, dat hij niet wilde spreken over de vraag of de ziel onsterfelijk is, noch over de vraag of de mens na de dood voortbestaat, ondat dat kwesties waren die „in de theologie" moesten worden behandeld. 
Bij zulk een opvatting isoleert men echter zijn geloof en zijn beginsel van zijn wetenschapsbeoefening; en door zulk een opmerking tracht men zichzelf de weg vrij te maken voor een gedrag waarbij men de beginselen in feite negeert. Want een beginsel is óók een begin. Een begin, waaraan wij geloven; een begin, wat wij niet buiten ons leven en buiten ons denken kunnen plaatsen. Als iemand zou schrijven over de verhouding moederkind, en hij zou daarbij zeggen: over de vraag of een kind zijn moeder lief heeft praat ik niet, want dat ligt op het terrein van de ethiek, dan zou ieder gerechtigd zijn op te merken, dat deze man wel een stuk uit zijn leven moet hebben weggesneden, voor hij over zijn onderwerp sprak. Maar meer nog dan de liefde tot onze moeder in onze ziel vergroeid zit, ligt voor hem, die gelooft, het beginsel vast in zijn hart, en in heel zijn zijn, ook als hij begint met wetenschappelijke dingen.

Als ik spreek over de mens, kan ik die mens niet isoleren van datgene wat ik omtrent hem, en dat is ook omtrent mijzelf zeker weet, omdat ik het geloof.

En nu ligt juist een van de belangrijkste problemen van deze tijd in de situatie, die wij hier aanraken.

De moderne wetenschap werpt allerlei problemen op. Maar bij het stellen van de problemen maakt men het apriori los van datgene wat naar Christelijke overtuiging de basis en de wortel van de problematiek is. Vandaar ook dat de practijk van het leven, die steeds de invloed van de wetenschap ondergaat, voortdurend opnieuw ten opzichte van de mens en de menselijke beleving zich emancipeert van de openbaring Gods en zich verarmt tot een benauwende angsthouding, die slechts eigen beperktheid demonstreert.

Men wil vrij zijn in zijn denken, daarom maakt men het begrip vrijheid los van zijn religieuze basis, waarin het veilig is. Want in zijn religieuze zin beteekent het: los-zijn van al die banden die vreemd zijn aan ons wezen, maar sluit het tevens in: gebonden zijn door alle banden die behoren bij het wezen. Voor niet-menselijke schepselen erkent men deze zin van vrijheid wel. Een vis is alleen vrij als hij gebonden is aan het water, omdat het water bij zijn wezen behoort. Maar wanneer men voor de mens vrijheid vraagt, dan wordt die vrijheid geëmancipeerd van zijn religieuze zin, en maakt men er vrijzinnigheid van, om dan via vrijzinnigheid het zelfbeschikkingsrecht van de mens als ideale vorm van de vrijheid te poneren. 
Op dezelfde wijze haalt men, door het losmaken van de dagelijkse arbeid uit de religieuze sfeer, het werk van de mens naar beneden. Door uit het beroep het roepingselement te verwijderen wordt het beroep een baantjie, en het baantjie tot een noodzakelijk kwaad, waarmee men zijn economisch bestaan mogelijk maakt.

Dezelfde tragische ontwikkeling van de feiten zien wij in de beschouwingen over het zieleleven van de mens. Een van de kostelijkste dingen, die God aan de mens gegeven heeft, is gelegen in het feit dat, uit zijn religieus zijn, in zijn houding tegenover God en schepselen zowel eroos als aidoos naar voren komen. Maar maakt men de eroos los van de religieuze wortel, dan wordt zij gericht op het stoffelijk bestaan der schepselen en via een egocentrische erotiek gaat zij straks op in een steriele sexualiteit.

En als de aidoos los gemaakt wordt van de religieuze basis, dan zijn er twee mogelijkheden: of aidoos, de schroom, ontwikkelt zicht tot vrees, en uit de vrees groeit de angst, die vandaag object is van een nieuwe wetenschappelijke cultus,--ofwel de mens, die zijn aidoos, zijn religieus verwortelde schroom opzij zet, wordt de brutale en straks de brute overweldiger van het leven.

Als wij dit bedenken behoeft het geen nader betoog, hoezeer het voor de Calvinistische wetenschap van betekenis is, steeds weer vast te houden aan de gedachte dat de mens in heel zijn zijn religieus is, en slechts als religieus wezen kan worden verstaan in zijn eigenlijke zijn. Evenzeer is het duidelijk dat hij slechts vanuit de religieuze visie wetenschappelijke en practische lessen ontvangen kan over de zin van het leven, dat hem te leven gegeven is.

$\mathrm{Nu}$ is er in onze tijd naar het schijnt wel een neiging tot verdieping van het leven.

Een psycholoog als Jung erkent tenminste dat er religie is. Maar altijd weer blijft het religie, die slechts betrokken is op het eigen zijn van de mens. In de immanentie van zijn eigen bestaan bevindt die mens zekere tendenzen, die hij religie noemt. Terecht wordt dan ook door Buber opgemerkt dat Jung met het transcendente te weining rekening houdt. En als wij figuren als Binswanger en ook Buber zelf beschouwen, dan vinden wij inderdaad meermalen een betoog, dat daartoe strekkende is, dat wij ook de betekenis van het transcendente in het leven moeten erkennen. Op zichzelf kan men natuurlijk dit alles waarderen. En nu is mijn critiek niet in de eerste plaats, dat wij alleen maar de methode kunnen toepassen, waarbij wij denken vanuit het transcendente. 
Een bioloog die een bloem onderzoekt moet de observerende methode toepassen. Psychologie is zonder experimenten niet mogelijk, en wij kunnen geen physica doen zonder metingen. Zo kunnen wij ook erkennen de waarde van de phenomenologische methode in de psychologie. Wie weten wil wat angst is, zal de phainomena van het angstig zijn van de mens moeten kennen.

Maar daar ligt dan ook mijn bezwaar niet. Mijn bezwaar is dat men denkt het leven en het levensgebeuren te kunnen verstaan zonder te denken vanuit de principiële grond.

Wie spreekt over de mens, spreekt niet over een abstract iets, maar over een wezen dat reëel bestaat. Beslissend voor de uitslag van elke studie over de mens is het antwoord op de vraag, wat men onder "mens" verstaat. Ik heb dikwijls de indruk, dat dit enerzijds zo vanzelf sprekend is, dat het bijna dwaasheid schijnt, om het met nadruk te zeggen. Maar anderzijds vindt men door personen met zeer verschillende levensovertuiging, gedachten gepubliceerd, die aangediend worden als objectief zeker, zonder dat daarbij wordt aangegeven van welke grondstelling men uitgaat.

$\mathrm{Nu}$ bedoel ik allerminst te zeggen (en dat is feitelijk een herhaling van wat $\mathrm{ik}$ zoëven opmerkte) dat bij iedere publicatie van geconstateerde feiten, deze grondhouding van invloed hoeft te zijn.

Drie personen, van geheel verschillende levensovertuiging, kunnen in hun laboratoria tot precies dezelfde conclusies komen omtrent bepaalde feiten. Maar bij het constateren van zulke feiten moge men al wetenschappelijk bezig zijn,--men bouwt er niet een wetenschap mee op.

Om een wetenschap op te bouwen moet men de zin van de totaliteit, en de totaliteit van de zin van het bestudeerde trachten te verstaan. En dit verstaan nu van de zin is slechts mogelijk wanneer men omtrent de zin van de mens, omtrent zijn betekenis, omtrent zijn diepste zijn, een overtuiging heeft.

Wat ik hier bedoel is dan ook iets anders dan wat men noemt: erkenning van het transcendente. Men kan dit transcendente toch nog weer in feite kosmisch maken, door het zijn eigen zijn als wezenlijk transcendent en staande boven een schepsel, te ontnemen. Men kan het ook als transcendente realiteit krachteloos maken door het te ontpersoonlijken en het zo in een vage strekking te doen opgaan; waarbij dan het transcendente niet anders wordt dan een belevingsbehoefte van de mens in zijn existentie.

Het wezenlijke van het transcendente is dat het existentieel is. Dat is dat het maar niet teen Het is, maar een $\mathrm{Hij}$. Alleen in de relatie Ik-Hij, 
die voor het geloof dan Ik-Gij wordt, is waarachtige religie mogelijk. En dat deze religie mogelijk is komt omdat de mens door God geschapen is naar Zijn beeld en Zijn gelijkenis, zó dat hij nu religieus is, aangelegd op God. En omdat deze mens religieus is, daarom is hij mens en kan hij als mens existeren, daarom kan hij eroos en aidoos beleven. Daarom kan hij vrij zijn, en roeping beleven; daarom kan hij denken en voelen, streven en willen. Menselijk psychische vermogens bestaan dus slechts als menselijke vermorgens, wijl zij vermogens zijn die in het religieuze zijn van de mens verankerd liggen. Het losmaken van deze vermogens van hun basis, betekent dus een denaturering van de mens. Maar het betekent ook, dat het recht verstaan van deze psychische mogelijkheden en van dat psychische functioneren alleen maar daar aanwezig kan zijn, waar men deze grondrelatie erkent, en gelovig kennend met wetenschappelijke methoden doorziet.

Maar daarmee is ook gezegd, dat een „,wetenschappelijk” opstel, dat met citaten van "allerlei" mensen tracht inzicht te geven omtrent het wezen van leven, en dan het betoog doorspekt met enige bijbelteksten, nog helemaal geen Christelijke visie behoeft weer te geven.

Dc psychologie is, Calvinistisch gedacht, niet: „wat behaviourisme” en „wat experiınenten” en ,wat sociale begrippen” en „een paar filosofische zinnen" en "enige bijbelteksten” door elkaar gemengd tot een wetenschappelijke koek, maar psychologie is de wetenschap van het psychisch leven van de mens, zoals God hem gemaakt heeft; dus een wetenschap gedacht vanuit de schepping en vanuit het leven zoals God het heeft geformeerd.

Dit betekent ook dat de psychologie begrensd is door haar opgave. Psychologie wil beschrijven en verstaan (dus niet alleen maar beschrijven! tegelijk begrijpen!) het psychisch leven van de mens.

Maar daarmee is dan ook gezegd dat bijvoorbeeld paedagogiek wat anders is dan toegepaste psychologie. De toegepaste psychologie heeft altijd betrekking op het constateren van het zijn en op het verstaan van het zijnde.

Paedagogiek daarentegen is een geheel ander soort wetenschap. De paedagogiek beschrijft wat er gebeuren moet bij de opvoeding van een kind. Paedagogiek geeft dus voorschriften. Daarom is het een normwetenschap.

Maar indien ergens, dan is het vooral bij deze paedagogiek duidelik, dat men een uitermate gevaarlijke weg bewandelt wanneer men het kind 
dat opgevoed moet worden, en de mens die opvoedt, en de normen en de regels die men gebruikt bij die opvoeding, en de doelstellingen die men zicin stelt, los maakt van hun religieuze basis. Noch de gemeenschap, noch het individuele kind, noch de nationale samenleving, kan de normen bieden voor een Christelijke opvoeding. Heel de opvoedingsactiviteit is religieus verworteld in datgene, wat wij het wezen, de zin en het doel van het leven van de mens kunnen noemen. En het sociale en het nationale groeien dan uit dezelfde religieuze wortel.

Wie dit verstaat, die ziet de enorme gevaren, welke de pragmatistische opvoeding (Dewey) over de wereld heeft gebracht.

De zin der Christelijke opvoeding ligt altijd verbonden aan de schepping en aan het levensdoel van de mens. Daarom is die opvoeding niet los te maken van het vraagstuk van zonde en genade. Daarom is een "neutrale" opvoeding geen opvoeding in de eigenlijke zin. Want zij miskent de aard van het kind, en zij verstaat niet het uitgangspunt en het doel van alle opvoeding.

Ook de opvoeding aan een universiteit die zich Calvinistisch noemt, zal slechts vanuit deze grondgedachte mogen worden beoefend. En slechts met deze grondhouding heeft een Calvinistische universiteit, waar deze ook gesticht is, onder Gods zegen, mogelijkheden voor de toekomst. 